\title{
The Effect of Earning Per Share, Price to Book Value, Dividend Payout Ratio, and Net Profit Margin on the Stock Price in Indonesia Stock Exchange
}

\author{
Bustani \\ Kurniaty \\ Rahmi Widyanti \\ Management, Universitas Islam Kalimantan Muhammad Arsyad Al Banjari, Indonesia \\ Author correspondence: bustani1993@gmail.com
}

\begin{abstract}
Fundamental analysis of companies with financial ratios is essential in making investment decisions for any company. Therefore, to obtain maximum profit, investors need to perform a study before making investment decisions. This research aims to examine the effect of Earning Per Share (EPS), Price to Book Value (PBV), Dividend Payout Ratio (DPR), and Net Profit Margin (NPM) on the stock price. The research at the Indonesia Stock Exchange, a sub-sector of food and beverage companies, period five years (2014-2018). The sample of this study amounted to 12 companies from 26 companies in the population of food and beverage companies that have met the researchers' criteria. Data analysis with bootstrapping used SEM (statistical equation modeling) in hypothesis testing. The research findings confirmed the significant effect of Earning per Share, Price to Book Value, and Dividend Payout Ratio on stock prices. Meanwhile, the Net Profit Margin does not significantly affect stock prices in the study period, with an alpha significance of five percent. These findings imply practical implications that EPS, PBV, DPR, and NPM ratio information can be considered in investment decisions for anyone.
\end{abstract}

Keywords: Earning Per Share (EPS); Price to Book Value (PBV); Dividend Payout Ratio (DPR); Net Profit Margin (NPM); Stock Price.

Abstrak. Analisis fundamental pada perusahaan dengan menggunakan rasio keuangan sangat penting untuk membuat keputusan investasi bagi perusahaan mana pun. Oleh karena itu, untuk mendapatkan keuntungan maksimal, investor perlu melakukan kajian sebelum mengambil keputusan investasi. Penelitian ini bertujuan untuk mengkaji efek Earning per Share (EPS), Price to Book Value (PBV), Dividend Payout Ratio (DPR), dan Net Profit Margin (NPM) terhadap harga saham. Penelitian ini dilaksanakan di Bursa Efek Indonesia, sub-sektor perusahaan makanan dan minuman untik periode lima tahun (2014-2018). Sampel penelitian ini berjumlah 12 perusahaan dari 26 perusahaan dalam populasi perusahaan makanan dan minuman yang telah memenuhi kriteria peneliti. Analisis data dengan bootstrapping menggunakan SEM (statistical equation model) melalui pengujian hipotesis. Temuan dalam penelitian ini mengkonfir- 
masi bahwa Earning per Share, Price to Book Value, dan Dividen Payout Ratio berpengaruh signifikan pada harga saham. Sementara itu, Net Profit Margin tidak berpengaruh signifikan terhadap harga saham pada periode penelitian dengan signifikansi alfa lima persen. Temuan ini berimplikasi penting pada kegunaan informasi rasio EPS, PBV, DPR, dan NPM dalam pertimbangan keputusan investasi. Temuan ini menyiratkan implikasi praktis bahwa informasi rasio EPS, PBV, DPR, dan NPM dapat dipertimbangkan dalam keputusan investasi bagi siapa pun.

Kata kunci: Earning Per Share (EPS); Price to Book Value (PBV); Dividend Payout Ratio (DPR); Net Profit Margin (NPM); Harga saham.

Article Info:

Received: February 24, 2021

Accepted: May 24, 2021

Available online: August 2, 2021

DOI: http://dx.doi.org/10.30588/jmp.v11i1.810

\section{BACKGROUND}

Indonesia's economic development has implications for competition intensity between increasing companies (Risnanti, Kustiyah, \& Widayanti, 2019). That is it, the progression of the Indonesian stock market has considerably increased (Sanjaya \& Afriyenis, 2018). Indonesia's growing economy has made companies increase their value to compete globally (Anwar, 2019). Currently, the Indonesia Stock Exchange has nine industrial sector classifications, including food and beverage companies. Food and beverage companies contributed to investment in Indonesia in 2018, amounting to IDR56.60 trillion. This company has also grown by 7.91\%, which exceeds Indonesia's economic growth by 5.17 percent (Yulyanah \& Kusumastuti, 2019). Food and beverage companies also contribute to Indonesia's Gross Domestic Bruto or GDP (Gumanti, Ningrum, Paramu, \& Soendjoto, 2020). This company is also more robust against the economic crisis than in other sectors because some food and beverage products are still needed to meet most of society's basic needs (Jurnal Entrepreneur, 2020). Besides, this company has favorable prospects both now and in the future. This series of food and beverage companies have appealed to most investors in making investment decisions. Investors must have a good knowledge of the investment product chosen (Suganda \& Sabbat, 2014).

Stock prices are an essential factor to consider for investors, makers, and other stakeholders (Hashmi, Chang, \& Bhutto, 2021). Research by Yin and Nie (2021) explores the predictive capabilities of cash dividend ratio and share price with cash dividend ratio yield having positive predictive power during the sample period from 2002 to 2018. However, this study only investigated dividends' relationship to stock prices, focusing on cash dividends' role in driving stock price variations. However, many other factors can affect stock prices, so researchers are interested in adding new variables that can affect stock prices, such as EPS, PBV, DPR, and NPM. Many studies have been done before, but they have inconsistent results, such as in the following studies.

First, the Earning per Share (EPS) ratio affects the stock price significantly (Adi, Darminto, \& Atmanto, 2013; Ariyani, Andini, \& Santoso, 2018; Cahyaningrum \& Antikasari, 2017; Dewi \& Suaryana, 2013; Egam, Ilat, \& Pangerapan, 2017; Fauza \& 
Mustanda, 2016; Girsang, Tambun, Putri, Rarasati, Nainggolan, \& Desi, 2019; Kusumawati, Topowijono, \& Endang NP., 2016; Lestari \& Susetyo, 2020; Sanjaya \& Afriyenis, 2018; Sochib, 2019; Sulistyowati, 2011). However, the EPS ratio changes from the research findings, but has no significant effects on the stock price (Darnita, 2012; Faleria, Lambey, \& Walandouw, 2017). Second, the Price to Book Value (PBV) ratio significantly affects the stock price (Adi et al., 2013; Ariyani et al., 2018; Cahyaningrum \& Antikasari, 2017; Lestari \& Susetyo, 2020; Sanjaya \& Afriyenis, 2018; Sochib, 2019). However, it is different from the research results that the PBV ratio has no significant effect on the stock price (Beliani \& Budiantara, 2017; Dewi \& Suaryana, 2013).

Third, the Dividend Payout Ratio (DPR) significantly affects the stock price (Bailia, Tommy, \& Baramulli, 2016; Bulutoding, Parmitasari, \& Dahlan, 2018; Devi, Mardani, \& Salim, 2016; Ermiati, Amanah, Harahap, \& Siregar, 2019; Fauza \& Mustanda, 2016; Hakami, 2018; Ningrum, 2017; Nugraha \& Sudaryanto, 2016; Salam \& Rohaida, 2019; Silalahi \& Manik, 2019; Sulistyowati, 2011). However, it is different from the research results the DPR has no significant effect on the stock price (Bailia et al., 2016; Girsang et al., 2019; Hanryono, Riwoe, \& Setiawan, 2017). Fourth, the Net Profit Margin (NPM) ratio significantly affects the stock price (Bustani, 2020; Darnita, 2012; Egam et al., 2017; Ningrum, 2017; Ramadhana, Sjahruddin, \& Purnomo, 2013). However, it is different from the research results the PBV ratio has no significant effect on the stock price (Dini \& Indarti, 2012; Faleria et al., 2017; Hutapea, Saerang, Tulung, Manajemen, Sam, \& Manado, 2017; Lestari \& Susetyo, 2020).

In this research, signaling Theory provides financial ratio information signals, namely: EPS, PBV, DPR, and NPM, that can describe important information for investors in investment decision making. Information published as an announcement will provide a signal for investors in investment decision-making. If the announcement contains a positive value, it is expected that the market will react at the time the announcement is received by the market (Novalia \& Nindito, 2016). If the financial information has a good rating, then the investor's information is good news so that the investor is interested in trading shares and leads to changes in the share price. Conversely, if financial information shows low valuation, investors' information is terrible news and affects trading and stock prices (Khairudin \& Wandita, 2017; Mayangsari, 2018). Signaling Theory explains how a company should give signals to users of financial statements. The signal is either a piece of information about a company's condition to the owner or interested parties - signals given in the form of important company information stating that it is better than other companies. Signaling Theory can reduce misinformation between management and outside parties, in this case, investors (Mediawati \& Afiyana, 2018).

As for this study's underlying background, due to inconsistencies in previous research results, some say that earnings per share, price to book value, dividend payout ratio, and net profit margin affect the share price. However, not a few also say earnings per share, price to book value, dividend payout ratio, and net profit margin do not affect the stock price, so re-research is needed. Most of the analysis tools used use regression in previous studies. Researchers must use new analysis tools that use SEM to test the effect of EPS, PBV, DPR, and NPM on stock prices on Food and Beverage Companies in Indonesia Stock Exchange for 2014-2018. 


\section{THEORETICAL REVIEW}

\section{The influence of EPS on stock prices}

Based on signaling theory, the company's Earning Per Share (EPS) number in the financial statements can give investors the right news signals (Khairudin \& Wandita, 2017). Signaling Theory is a concept where the informant can choose what and how the information will be displayed, and the receiving party can choose how to interpret the information received (Connelly, Certo, Ireland, \& Reutzel, 2011). A good company can distinguish itself from a bad company by sending a reliable signal about its quality to the capital market. Signaling Theory is the information signals needed by investors to consider and determine whether investors will invest their shares in the company. Information about changes in the price and volume of shares contains information in providing useful evidence and can be used in decision making (Suwardjono, 2011). EPS can be formulated in equation [1] (Dewi \& Suaryana, 2013).

$$
\text { Earning Per Share (EPS) }=\frac{\text { Earning After Tax }}{\text { Number of Shares Outstanding }}
$$

EPS is part of the profitability ratio by calculating profit by the number of shares minus tax expense (Faleria et al., 2017). EPS can also be accounting-based indicators mainly used to measure a firm's financial performance (Albertini \& Berger-Remy, 2019). The EPS ratio looks at the strength of a company in generating earnings based on earnings per share. EPS, therefore, determines the amount of revenue earned to sustain a corporation from each share it shares (Ratih, Apriatmi, \& Saryadi, 2016). For each share, the EPS ratio provides information about net income. In particular, when the EPS ratio increases and decreases, it impacts stock prices (Indahsafitri, Wahono, \& Khoirul ABS., 2015; Lestari \& Susetyo, 2020; Watung \& Ilat, 2016). The EPS ratio is a measuring tool to see an overview of a company's information in making investment decisions. Thus, if net income is high, investors will like it. The first hypothesis (H1) tested in this study, based on this description, can be formulated as follows:

\section{H1: EPS has a significant effect on stock prices.}

\section{The influence of PBV on stock prices}

The company's value in the signaling theory represented by Price to Book Value (PBV) is crucial to signal information given by the company to external parties, so this signal indicates that the company is transparent in its management. In signaling theory, the value of Price to Book Value can provide good news / positive signals to investors (Khairudin \& Wandita, 2017). PBV can describe the data on the book value of a company's shares (Nasihah, 2017). A high PBV ratio is a factor of confidence in its prospects (Lestari \& Susetyo, 2020). A high PBV ratio value characterizes good financial performance. If the company has a good performance, the PBV ratio will increase (Cahyaningrum \& Antikasari, 2017). Thus, in investment considerations for investors, PBV is an essential financial ratio because PBV can describe a company's total book value. PBV can be formulated in equation [2] (Dewi \& Suaryana, 2013). 


$$
\text { Price to Book Value }(\text { PBV })=\frac{\text { Stock Market Price }}{\text { Book Value Per Share }}
$$

Therefore, if the company's book value has a high value, it can encourage investors because investors believe that if the company's book value is high, investors will believe that it can maximize profit. The second hypothesis (H2) tested in this research is formulated as follows:

\section{H2: PBV has a significant effect on stock prices.}

\section{The influence of DPR on stock prices}

Based on signaling theory, the announcement of dividend distribution is a signal given by the company specifically to describe the company's future profitability prospects (Suganda \& Sabbat, 2014). Dividend payout ratio (DPR) is the ratio received in cash by shareholders based on a percentage of profit earned (Lestari \& Susetyo, 2020). DPR describes the company's ability to divide profit results, so the higher the market demand, the higher the share price, the greater the investors' desire to buy the company's shares (Ermiati et al., 2019; Gumanti, 2013; Pranata, Purnamawati, \& Adiputra, 2015). For investment considerations, DPR is a financial ratio that is also very important for investors because DPR can describe the profit obtained from a business. DPR can be formulated in equation [3] (Hanryono et al., 2017).

$$
\text { Dividend Payout Ratio (DPR) }=\frac{\text { Dividend Per Share }}{\text { Earning Per Share }}
$$

Therefore, if the company offers maximum profit, it can attract investors because investors believe that if the company's profit is high, investors trust the company to provide maximum profit. Based on the description, the third hypothesis (H3), tested in this study, is formulated as follows:

\section{H3: DPR has a significant effect on stock prices.}

\section{The influence of NPM on stock prices}

Signaling theory is a concept where the informant can choose what and how the information will be displayed, and the receiving party can choose how to interpret the information received (Connelly et al., 2011). Net Profit Margin (NPM) describes the correlation between net profit minus tax expense and controlled costs, thus demonstrating management's ability to manage the company (Kasmir, 2012). NPM also shows how much net profit resulted from total sales (Chandrakala, 2019). If an increase in net profit does not offset the increase in sales results, then the NPM ratio will decrease (Egam et al., 2017). The relationship between net profit after tax and net sales demonstrates management's ability to drive the company successfully enough to leave certain margins as reasonable compensation for owners who have provided their capital for a risk (Simorangkir, 2019). NPM can be formulated in equation [4] (Faleria et al., 2017). 


$$
\text { Net Profit Margin }\left(\text { NPM) }=\frac{\text { Earning After Tax }}{\text { Net Sales }}\right.
$$

The stock price will rise if the investor makes a stock purchase because investors believe the company can make a big profit (Watung \& Ilat, 2016). If the company can generate a high net profit, then the NPM ratio is also high (Ambarwati, Enas, \& Lestari, 2019; Darnita, 2012; Hutami, 2012; Ningrum, 2017). If the company can earn a net profit, the investor will be encouraged to invest in such shares to impact the market price (Indahsafitri et al., 2015; Watung \& Ilat, 2016). Net Profit Margin is a financial ratio that is also very important for investors in investment considerations. Profitability depends on a low cost on its potential to raise its profits and tame its expense structure by strategies of cost management (Oyedokun, Tomomewo, \& Owolabi, 2019). To comprehensively perform the company's risk management approach, investors can identify the most critical processes and activities necessary to sustain the business's sustainability and meet its responsibilities to stakeholders in the event of a risk (Senkus \& Górna, 2021). If the company can make a net profit, investors will be interested in buying the shares, and this will cause the market price will rise (Watung \& Ilat, 2016). Therefore, the cost of goods sold and the company's operating costs remain efficient, so investors are confident of the maximum profit. The fourth hypothesis (H4) tested in this research as follows:

\section{H4: NPM has a significant effect on stock prices.}

\section{RESEARCH METHODS}

The research method is a scientific way to obtain data with specific purposes and uses (Sugiyono, 2017). Explanatory became the research method of this research by testing EPS as the first exogen variable with a symbol of $\mathrm{X} 1$, the second exogen variable PBV with a symbol of X2, the third exogen variable DPR with a symbol of X3, and the fourth exogen variable NPM with a symbol of X4 on stock price as the endogenous variable with a symbol of $\mathrm{Y}$. This research has been conducted at the Indonesia Stock Exchange, in a Food and Beverage sub-sector for the 2014-2018 observation period.

Table 1. Sample Criteria

\begin{tabular}{clcc}
\hline No. & \multicolumn{1}{c}{ Sample Criteria } & $\begin{array}{c}\text { Does Not Meet } \\
\text { Sample Criteria }\end{array}$ & $\begin{array}{c}\text { According to } \\
\text { Sample Criteria }\end{array}$ \\
\hline 1 & $\begin{array}{l}\text { Food and beverage companies listed on the Indonesia } \\
\text { Stock Exchange for 5 (five) consecutive years, 2014- } \\
\text { 2018. }\end{array}$ & 13 & 13 \\
\hline 2 & $\begin{array}{l}\text { Food and beverage companies that published full } \\
\text { financial statements to the Indonesia Stock Exchange's } \\
\text { official website for the period 2014-2018. }\end{array}$ & 1 & 12 \\
\hline 3 & $\begin{array}{l}\text { Food and beverage companies that provide data related } \\
\text { to research variables. }\end{array}$ & $\mathbf{1 4}$ & $\mathbf{1 2}$ \\
\hline
\end{tabular}

Source: Indonesia Stock Exchange (2020). 
The data source from the Indonesia Stock Exchange publication through websites of Indonesia Stock Exchange (2020) and Yahoo Finance (2020). By determining the considerations or criteria, the author chooses purposive sampling techniques, namely food and beverage companies listed on the Indonesia Stock Exchange for five consecutive years for 2014-2018, and publishes the full financial statements, and provides the variable information studied. A sample of 12 companies from 26 populations of food and beverage companies have met researchers' criteria. Table 1 shows the sample data selection process in this research.

Based on data in Table 1, food and beverage companies listed on the Indonesia Stock Exchange for the period 2014-2018 were selected as a research sample, namely the total population of 26 companies. Some companies do not meet the sample criteria that have been determined by researchers, namely 14 companies. So that, the samples studied are 12 companies multiplied by five years to a total of 60 data. The data analysis in this study uses hypotheses testing with boostraping in the Structural Equation Modelling-Partial Least Square (SEM-PLS) using SmartPLS 3.3.2. The criteria for hypothetical decision-making is probability (p-value). If the p-value is less than alpha $5 \%$, then the proposed hypothesis can be accepted. Otherwise, if the p-value is more than alpha 5\%, then the proposed hypothesis can be rejected.

\section{RESULTS AND DISCUSSIONS}

\section{Results}

\section{Description of Research Variables}

\section{a. Description of EPS Variable}

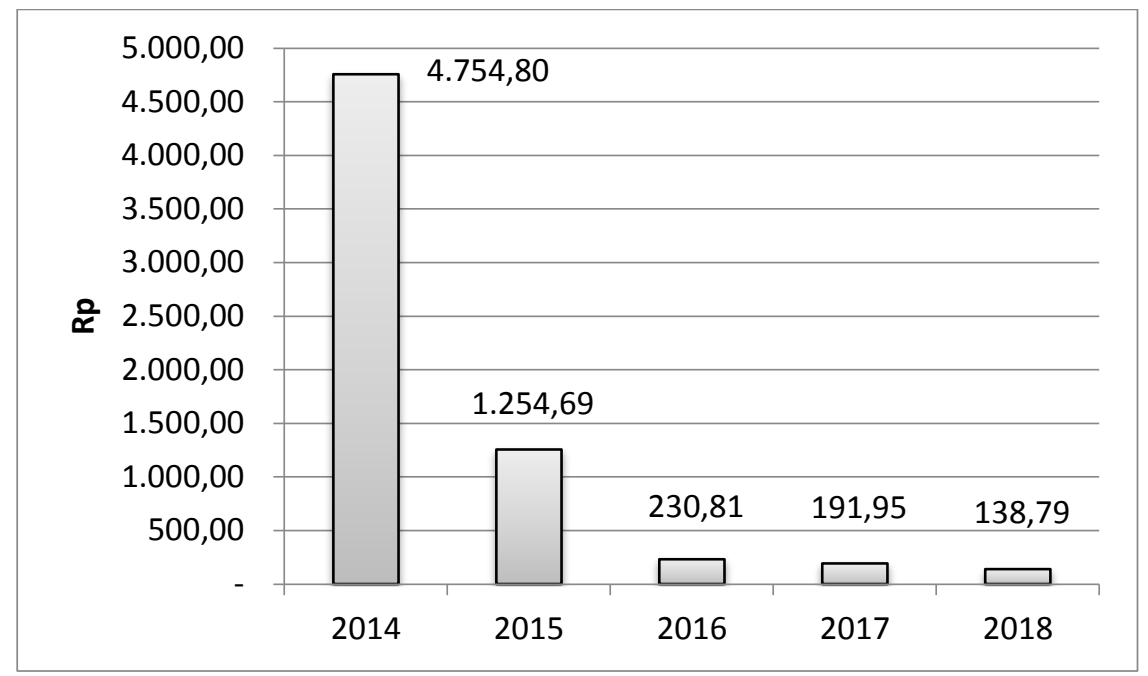

Source: Processed data (2020).

Figure 2. Average of the EPS ratio from 2014-2018

Based on Figure 2, the average EPS ratio of food and beverage companies on the Indonesia Stock Exchange period 2014-2018 tends to decrease the EPS ratio. However, the EPS ratio is a gauge to know how much net profit the company generates to 
consider investment decisions. Thus if the EPS ratio occurs to decrease, of course, investors must be careful in making investment decisions. EPS ratio describes the company's state in allocating and generating corporate profits, thus providing a benchmark for its success. Therefore the company is always required to increase the strength in generating net profit to assess its good condition. At the right time, investors choose this company as the object of investment. High profitability, certainly favored by investors.

\section{b. Description of PBV Variable}

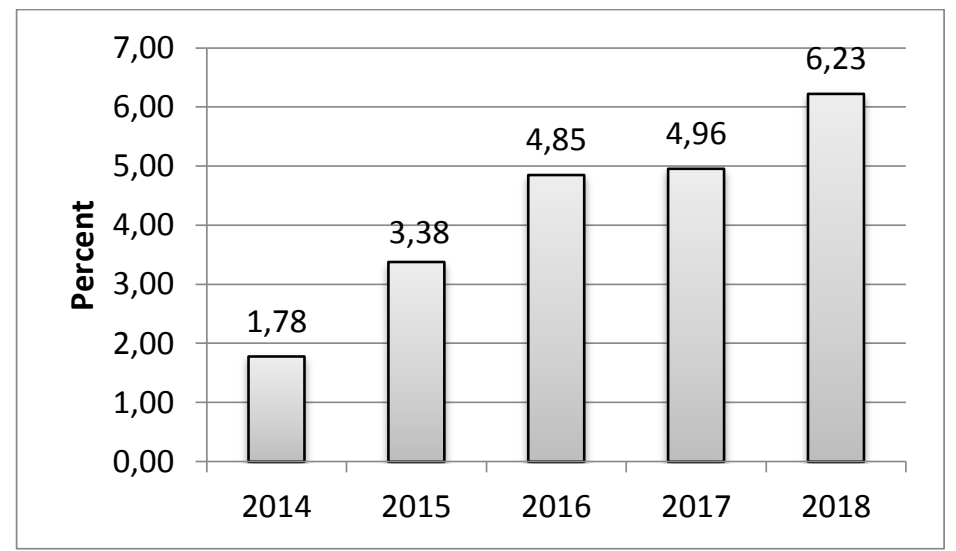

Source: Processed data (2020).

\section{Figure 3. Average of the PBV ratio from 2014-2018}

Based on Figure 3, the average PBV ratio in 2014-2018 tends to increase. However, the PBV ratio is a measurement tool to know how much net profit the company generates to consider investment decisions. Thus the PBV ratio describes the total book value of a company in a given period. If the PBV ratio increases, investors can see that the company's book value is good so that investors are interested in investment decision-making. The PBV ratio gives an idea of how much the company is capable of meeting financial obligations. Therefore, the strength of corporate liquidity is essential in resolving the company's financial obligations.

\section{c. Description of DPR Variable}

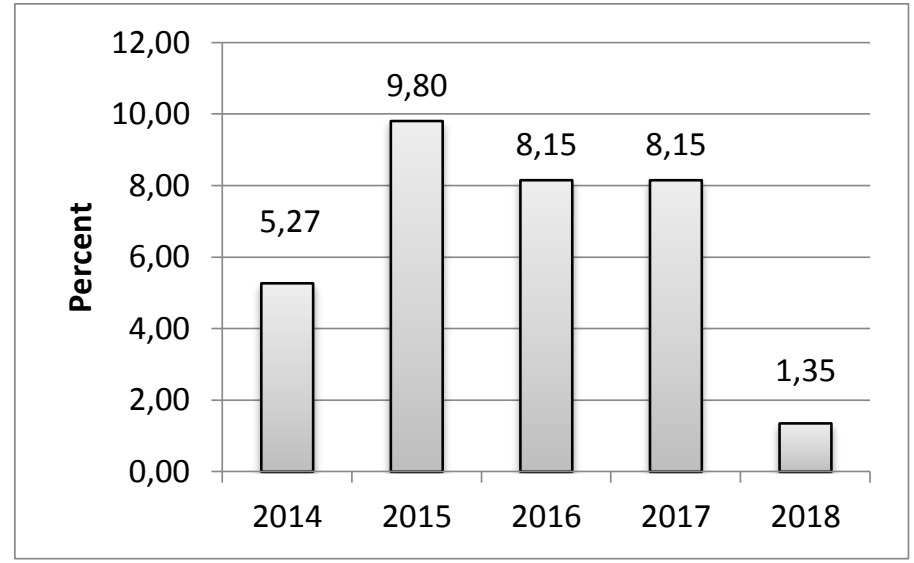

Source: Processed data (2020).

Figure 4. Average of the DPR ratio from 2014-2018 
Based on Figure 4, the ratio of DPR from 2014 to 2018 tends to occur fluctuations. However, the PBV ratio is a measurement tool to know how much net profit the company generates to consider investment decisions. Thus the PBV ratio describes the total book value of a company in a certain period. If the PBV ratio increases, investors can see that the company's book value is good so that investors are interested in investment decision-making. However, DPR is a financial ratio that is also very important in investment considerations for investors because DPR can describe the value of profits obtained from a company. Thus, if the company gives maximum profit, it can attract investors to make investments because investors believe if the company's profit is high, the investor considers that the company is worthy of being an investment object.

\section{d. Description of NPM Variable}

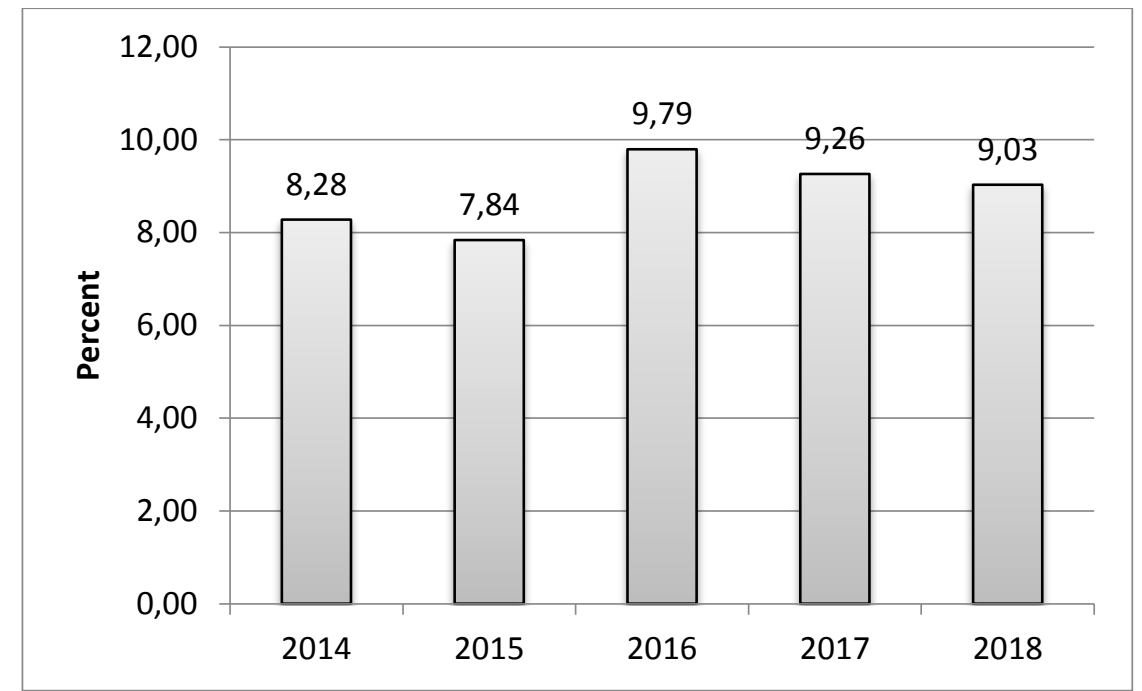

Source: Processed data (2020).

Figure 5. Average of the DPR ratio from 2014-2018

Based on Figure 5, the average NPM ratio from 2014 to 2018 tends to fluctuate. However, if the company can create a net profit, it can attract investors' interest in investing their funds. However, if the NPM ratio fluctuates, it could impact investors' lack of interest in investment decision-making. The NPM ratio shows the amount of the company's net profit to the sales results so that investors know whether the company can control the company's operating costs or not. However, if the NPM ratio is volatile, investors may see the company as inconsistent in controlling its operational costs, so investors will think about investing in a company.

\section{e. Description of Stock Price Variable}

Based on Figure 6, the average stock price from 2014 to 2018 is likely to increase, but there is a decline in 2015. However, suppose the company has an increasing stock price. In that case, the investor considers that the company can manage the company well to have good prospects, allowing companies to compete with other industrial sectors. 


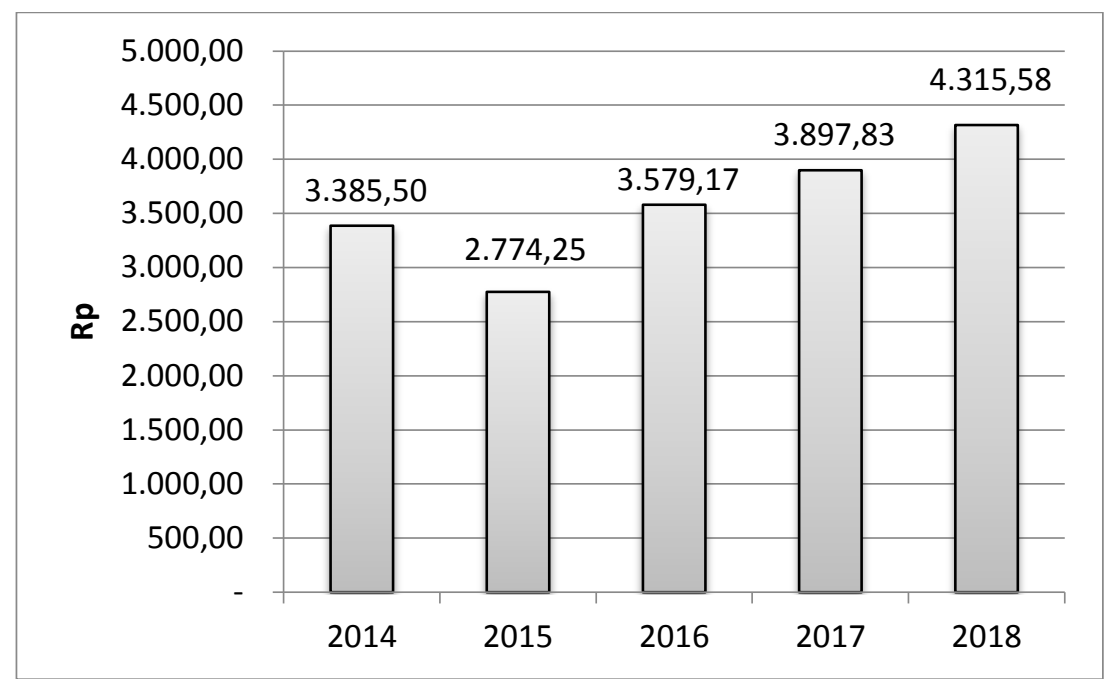

Source: Processed data (2020).

Figure 6. Average of the Stock Price from 2014-2018

\section{Hypothesis Test}

Bootstrapping results in hypothetical tests can be seen in the Table 1.

Table 1. Bootstrapping Results in Hypotheses Testing

\begin{tabular}{|c|c|c|c|c|c|}
\hline & $\begin{array}{c}\text { Original } \\
\text { Sample }(O)\end{array}$ & $\begin{array}{l}\text { Standard } \\
\text { Deviation } \\
(\text { STDEV) }\end{array}$ & $\begin{array}{c}t \text {-statistics } \\
(|O / S T D E V|)\end{array}$ & $p$-values & Conclusion \\
\hline$E P S \rightarrow$ Stock Prices & 0.272 & 0.126 & 2.157 & 0.031 & H1 is accepted \\
\hline$P B V \rightarrow$ Stock Prices & 0.565 & 0.135 & 4.193 & 0.000 & $\mathrm{H} 2$ is accepted \\
\hline$D P R \rightarrow$ Stock Prices & 0.353 & 0.146 & 2.416 & 0.016 & H3 is accepted \\
\hline NPM $\rightarrow$ Stock Prices & 0.094 & 0.103 & 0.916 & 0.360 & $\mathrm{H} 4$ is rejected \\
\hline $\begin{array}{l}\text { R Square }=0.693 \\
\text { Alpha }=5 \%\end{array}$ & & & & & \\
\hline
\end{tabular}

Source: Data processed (2020).

Based on the results of hypotheses testing with boostrapping in Table 1 , it can provide interpretation as follows:

a. All exogenous variables used in this study, namely EPS, PBV, DPR, and NPM variables have positive original samples (O), which means that all exogenous variables are directly related to the stock price (endogenous variable).

b. The EPS has a statistical t-value of 2.157 or more than t-table 2.003, and p-value is 0.031 smaller than alpha $5 \%$ or 0.05 . The first hypothesis (H1) is accepted that EPS has a significant effect on the stock price.

c. The PBV has a statistical t-value of 4.193 or more than t-table 2.003 , and p-value is 0.000 less than alpha 5\%. Thus, the second hypothesis $(\mathrm{H} 2)$ is accepted that PBV has a significant effect on the stock price.

d. The DPR has a statistical t-value of 2.416 or more than from t-table 2.003 , and pvalue is worth 0.016 smaller than alpha $5 \%$. So, the third hypothesis (H3) is acceptable that DPR has a significant effect on the stock price. 
e. The NPM has a statistical t-value of 0.916 or less than t-table 2.003, and p-value is 0.360 greater than alpha $5 \%$. The fourth hypothesis $(\mathrm{H} 4)$ is not accepted. The result indicates that NPM has not a significant effect on the stock price.

f. The $\mathrm{R}$ square value is 0.693 , the result means that all exogenous variables used, namely EPS, PBV, DPR, and NPM, were able to explain the variations on endogenous variables, namely the stock price of $69.3 \%$, the remaining $30.7 \%$ explained by other variables that were not studied.

\section{Discussions}

\section{The effect of EPS on stock prices}

Based on the analysis results, using bootstrapping shows the variable EPS has a significant effect on the share price. Indicates that EPS can influence its share price on the Indonesia Stock Exchange, the food and beverage sub-sector for 2014-2018. Therefore, the first hypothesis is acceptable indicates that EPS has a significant effect on the stock price. These findings follow the Signaling Theory that any company's management's profit information to outside parties or investors may affect the stock price. This research support previous research that EPS has a significant effect on the stock price (Adi et al., 2013; Ariyani et al., 2018; Cahyaningrum \& Antikasari, 2017; Dewi \& Suaryana, 2013; Egam et al., 2017; Fauza \& Mustanda, 2016; Girsang et al., 2019; Kusumawati et al., 2016; Lestari \& Susetyo, 2020; Sanjaya \& Afriyenis, 2018; Sochib, 2019; Sulistyowati, 2011).

Shareholders certainly have ownership rights, thus providing a benchmark for how much the company can profit. Therefore, companies are always required always to try to increase the strength in generating net profit. Investors judge the company seriously in running the company, and at the right time, investors allocate funds by buying shares that impact the increase in the stock price.

\section{The effect of PBV on stock prices}

Based on the analysis results, using bootstrapping shows that PBV variables significantly affect the price. Thus the second hypothesis is accepted, which indicates the significant influence of PBV on the share price. PPV ratio shows an improvement in the company's management in running the company. These findings follow the Signal Theory that PBV represented companies' valuable information can influence the stock price. The higher the value of PBV provides hope for investors to get a more significant profit. This research's results are supported by (Adi et al., 2013; Ariyani et al., 2018; Cahyaningrum \& Antikasari, 2017; Lestari \& Susetyo, 2020; Sanjaya \& Afriyenis, 2018; Sochib, 2019) that PBV has a significant effect on the stock price.

PBV ratio describes how strong the company is in completing obligations when the company is in a state of deterioration to anyone shareholder who certainly has ownership rights, thus providing a benchmark of its ability to accommodate all financial obligations. Therefore, the company is always required always to try to increase the strength in generating the company's value. Investors assess the company to provide liquidity and earnest guarantees in allocating corporate obligations when their condition deteriorates. Thus investors believe in the company. At the right time, investors allocate their funds by buying shares that impact the share price increase. 


\section{The effect of DPR on stock prices}

Based on the analysis results using bootstrapping shows that the DPR variable significantly affects the stock price in the Indonesia Stock Exchange stock price, a subsector of food and beverage companies for 2014-2018. Thus the hypothesis there is a significant influence of the Dividend Payout Ratio on the share price is acceptable. These findings follow the Signal Theory that dividend payment information is useful information to influence the stock price. The results of this research are supported by (Bulutoding et al., 2018; Devi et al., 2016; Ermiati et al., 2019; Fauza \& Mustanda, 2016; Hakami, 2018; Ningrum, 2017; Nugraha \& Sudaryanto, 2016; Salam \& Rohaida, 2019; Silalahi \& Manik, 2019; Sulistyowati, 2011) that PBV had a significant impact on the stock price.

DPR ratio is the ratio allocated by the company to any shareholder who certainly has ownership rights, but it also describes how much the company allocates in the company's operations. Investors are happier if the value of dividends. Because in a short period, investors can already enjoy the return on investment. Therefore, the company must generate net revenue and distribute it in real terms in dividends. So that investors judge the company seriously in giving a real profit in the eyes of investors. At the right time, investors increase the allocation of funds by buying shares of the company, thus impacting the share price. The greater the investment value of the invested shares, the hope of profit obtained in the future is also large.

\section{The effect of NPM on stock prices}

Based on the analysis results using bootstrapping shows that the NPM has no significant effect on the stock price. NPM cannot significantly influence the stock price, because the NPM ratio in achieving profit represents not all company, but only their sales (Hadi \& Nurhayati, 2018). In other words, the company has not been able to control the company's operational costs, so that the company's operational costs become inefficient. These findings follow the signaling theory that dividend payment information is useful information to influence the stock price. This finding follows the signal theory that dividend payment information is insufficient information to investors because high NPM is not necessarily a company that distributes cash dividends. Hence, NPM is not able to influence the share price in the research period. This study's results are supported (Dini \& Indarti, 2012; Faleria et al., 2017; Hutapea et al., 2017; Lestari \& Susetyo, 2020), NPM has no significant effect on the stock price.

NPM ratio measures the amount of net profit to the proceeds of the company's sale allocated to any shareholder who certainly has ownership rights. NPM ratio, investors can also see whether the company is efficient or not in corporate governance. Besides, investors can also project the company's profitability capabilities through sales forecasts made by the company. NPM ratio, investors can calculate how much the company spends on operational and non-operating costs and how proportional the profit is left to pay to shareholders in the dividends. Thus NPM ratio information can describe the level of efficiency of the company. Suppose the company can control the company's operational costs. In that case, there will be efficiency, and investors assess the company to make efficiency to the costs incurred, so investors believe the company can control operational costs. If the company cannot control operational costs, the investor will think about investing in a company. 


\section{CONCLUSIONS AND RECOMMENDATIONS}

Based on the results and discussions above, the conclussions of this research shows that Earning Per Share (EPS), Price to Book Value (PBV), and Dividend Payout Ratio (DPR) influenced the stock price on the Indonesia Stock Exchange for the Food and Beverage sub-sector from the 2014-2018 observation period. At the same time, Net Profit Margin (NPM) does not affect the stock price. However, fundamental analysis with financial ratios is an important thing to do before determining investment decisions to know the company's financial condition. This research also contributes to the development of science in economics generally, and financial management particularly. These findings imply practical implications that the information of EPS, PBV, DPR, and NPM ratio can be considered in investment decisions for anyone. However, this research is limited to the company's fundamental factors, so it does not assess factors outside the company, such as inflation and government policy. Thus in subsequent studies, it is necessary to add factors outside the company that affects the stock price.

\section{REFERENCES}

Adi, A., Darminto, D., \& Atmanto, D. (2013). Pengaruh Return on Equity, Debt to Equity Ratio, Earning per Share dan Book Value per Share terhadap Harga Saham (Studi pada Perusahaan Consumer Goods Industry yang Terdaftar di BEI Periode Tahun 2008-2011). Jurnal Administrasi Bisnis S1 Universitas Brawijaya, 4(2), 1-10.

Albertini, E., \& Berger-Remy, F. (2019). Intellectual Capital and Financial Performance: A Meta-analysis and Research Agenda. Management (France), 22(2), 216-249. https://doi.org/10.3917/mana.222.0216.

Ambarwati, P., Enas, E., \& Lestari, M. N. (2019). Pengaruh Net Profit Margin (NPM) dan Return on Equity (ROE) terhadap Harga Saham (Studi Kasus pada PT Bank Central Asia, Tbk. yang Terdaftar di Bursa Efek Indonesia Periode 2007-2017. Business Management and Extrepreneurship Journal, 1(2), 100-119.

Anwar, S. (2019). The Influence of Ownership Structure, Asset Structure, and Earning Volatility on Debt Policy in Indonesia (Study in Pharmaceutical Companies in Indonesia Stock Exchange). Journal of Accounting and Strategic Finance, 2(1), 93-106. https://doi.org/10.33005/jasf.v2i1.54.

Ariyani, L., Andini, R., \& Santoso, E. B. (2018). Pengaruh EPS, CR, DER dan PBV terhadap Harga Saham dengan Kebijakan Dividen sebagai Variabel Intervening (Studi pada Perusahaan Manufaktur yang Terdaftar di BEI Tahun 2011-2015). Journal of Accounting, 4(4), 1-20.

http://jurnal.unpand.ac.id/index.php/AKS/article/view/958.

Bailia, F. F. W., Tommy, P., \& Baramulli, D. N. (2016). Pengaruh Pertumbuhan Penjualan, Dividend Payout Ratio dan Debt to Equity Ratio terhadap Harga Saham pada Perusahaan Properti di Bursa Efek Indonesia. Jurnal Berkala Ilmiah Efisiensi, 16(3), 270-278.

Beliani, M. M. I., \& Budiantara, M. (2017). Pengaruh Price Earning Ratio dan Price to Book Value terhadap Harga Saham Perusahaan Asuransi yang Terdaftar di Bursa Efek Indonesia Tahun 2009-2012. Jurnal Riset Akuntansi Mercu Buana, 1(1), 7686. https://doi.org/10.26486/jramb.v1i1.12. 
Bulutoding, L., Parmitasari, R. D. A., \& Dahlan, M. A. (2018). Pengaruh Return on Asset (ROA) dan Debt to Equity Ratio (DER) terhadap Harga Saham dengan Kebijakan Dividen sebagai Variabel Intervening (Studi Empiris pada Perusahaan yang Terdaftar di Jakarta Islamic Index (JII) Periode 2010-2016). Journal of Chemical Information and Modeling, 53(9), 1689-1699.

Bustani, B. (2020). The Effect of Return on Assets (ROA), Net Profit Margin (NPM), Dividend Payout Ratio (DPR), and Dividend Yield (DY) on Stock Prices in the Sub-sector insurance Company Listed in Indonesia Stock Exchange Period 20152018. Ilomata International Journal of Tax \& Accounting, 1(3), 170-178.

Cahyaningrum, Y. W., \& Antikasari, T. W. (2017). Pengaruh Earning per Share, Price to Book Value, Return on Asset, dan Return on Equity terhadap Harga Saham Sektor Keuangan. Jurnal Economia, 13(2), 191-200. https://doi.org/10.21831/economia.v13i2.13961.

Chandrakala, N. (2019). A Study on Financial Performance of Indian Cement Companies with Reference to Selected Cements Companies. International Journal of Scientific and Technology Research, 8(9), 2128-2133.

Connelly, B. L., Certo, S. T., Ireland, R. D., \& Reutzel, C. R. (2011). Signaling Theory: A Review and Assessment. Journal of Management, 37(1), 39-67. https://doi.org/10.1177/0149206310388419.

Darnita, E. (2012). Analisis Pengaruh Return on Assets (ROA), Return on Equity (ROE), Net Profit Margin (NPM) dan Earning per Share (EPS) terhadap Harga Saham (Studi pada Perusahaan Food dan Beverages yang Terdaftar di Bursa Efek Indonesia (BEI) pada Tahun 2008-2012). Jurnal Ekonomi, 1(8), 1-16.

Devi, S. K., Mardani, R. M., \& Salim, A. (2016). Pengaruh Dividen Payout Ratio (DPR), Return on Equity (ROE), Financial Leverage (FL) dan Price Earning Ratio (PER) terhadap Harga Saham. E-Jurnal Riset Manajemen, 1(1), 108-121.

Dewi, P. D. A., \& Suaryana, I. G. N. A. (2013). Pengaruh EPS, DER, dan PBV terhadap Harga Saham. E-Jurnal Akuntansi, 4(1), 215-229.

Dini, A. W., \& Indarti, I. (2012). The Influence of Net Profit Margin (NPM), Return on Assets (ROA), and Return on Equity (ROE) on Stock Price Listed in Index Issuer LQ45 Period 2008-2010. Jurnal Kajian Akuntansi dan Bisnis, 1(1), 1-18.

Egam, G. E. Y., Ilat, V., \& Pangerapan, S. (2017). Pengaruh Return on Asset (ROA), Return on Equity (ROE), Net Profit Margin (NPM), dan Earning per Share (EPS) terhadap Harga Saham Perusahaan yang Tergabung dalam Indeks LQ45 di Bursa Efek Indonesia Periode Tahun 2013-2015. Jurnal EMBA, 5(1), 105-114. https://doi.org/10.1007/978-1-349-15400-5_6.

Ermiati, C., Amanah, D., Harahap, D. A., \& Siregar, E. S. (2019). Pengaruh Kebijakan Dividen terhadap Harga Saham Perusahaan Sub-Sektor Otomotif dan Komponen yang Terdaftar di Bursa Efek Indonesia Periode 2008-2017. Niagawan, 8(2), 131139. https://doi.org/10.24114/niaga.v8i2.14366.

Faleria, R. E., Lambey, L., \& Walandouw, S. K. (2017). Pengaruh Current Ratio, Net Profit Margin dan Earning per Share terhadap Harga Saham di Bursa Efek Indonesia (Studi Kasus pada Sub-Sektor Food and Beverages). Going Concern: Jurnal Riset Akuntansi, 12(2), 204-212. https://doi.org/10.32400/gc.12.2.17483.2017. 
Fauza, M., \& Mustanda, I. (2016). Pengaruh Profitabilitas, Earning per Share (EPS) dan Dividend Payout Ratio (DPR) terhadap Harga Saham. E-Jurnal Manajemen Universitas Udayana, 5(12), 8015-8045.

Girsang, A. N., Tambun, H. D., Putri, A., Rarasati, D., Nainggolan, D. S. S., \& Desi, P. (2019). Analisis Pengaruh EPS, DPR, dan DER terhadap Harga Saham Sektor Trade, Services, \& Investment di BEI. Jesya (Jurnal Ekonomi \& Ekonomi Syariah), 2(2), 351-362. https://doi.org/10.36778/jesya.v2i2.97.

Gumanti, T. A. (2013). Kebijakan Dividen: Teori, Empiris dan Implikasi, Edisi Pertama. Yogyakarta: UUP STIM YKPN.

Gumanti, T. A., Ningrum, I. S., Paramu, H., \& Soendjoto. (2020). Fundamental Analysis in Indonesia Stock Exchange. International Journal of Scientific and Technology Research, 9(3), 5101-5104.

Hadi, W., \& Nurhayati. (2018). Analysis of The Effect of Net Profit Margin, Return on Assets and Return on Equity on Stock Price (Case Study on Consumption Industrial Sector Companies Listed in Indonesian Sharia Stock Index at Indonesia Stock Exchange in 2016). The Management Journal of Binaniaga, 03(02), 81-92. https://doi.org/10.33062/mjb.v3i2.261.

Hakami, M. A. F. (2018). Pengaruh Kebijakan Dividen terhadap Harga Saham. Manajemen Bisnis, 4(1), 73-82. https://doi.org/10.22219/jmb.v4i1.5283.

Hanryono, H., Riwoe, J. C., \& Setiawan, N. (2017). Pengaruh Inflasi, Return on Asset dan Dividend Payout Ratio terhadap Harga Saham LQ45 (Periode 2006-2015).

Jurnal Muara Ilmu Ekonomi dan Bisnis, 1(1), 107-114. https://doi.org/10.24912/jmieb.v1i1.412.

Hashmi, S. M., Chang, B. H., \& Bhutto, N. A. (2021). Asymmetric Effect of Oil Prices on Stock Market Prices: New Evidence from Oil-exporting and Oil-importing Countries. Resources Policy, 70(December), 1-9. https://doi.org/10.1016/j.resourpol.2020.101946.

Hutami, R. P. (2012). Pengaruh Dividend per Share, Return on Equity dan Net Profit Margin terhadap Harga Saham Perusahaaan Industri Manufaktur yang Tercatat di Bursa Efek Indonesia Periode 2006-2010. Jurnal Nominal, 1(1), 104-123.

Hutapea, A. W., Saerang, I. S., Tulung, J. E., Manajemen, J., Sam, U., \& Manado, R. (2017). Pengaruh Return on Asset, Net Profit Margin, Debt to Equity Ratio dan Total Asset Turnover terhadap Harga Saham Industri Otomotif. Jurnal EMBA, 5(2), 541-551.

Indahsafitri, P. N., Wahono, B., \& Khoirul ABS., M. (2015). Pengaruh Return on Equity (ROE), Net Profit Margin (NPM), Gross Profit Margin (GPM) dan Earning per Share (EPS) terhadap Harga Saham (Studi Empiris pada Perusahaan yang Terdaftar dalam LQ45 BEI Periode 2013-2016). Jurnal Riset Manajemen, 1(1), 77-97. https://doi.org/10.1123/ijsb.8.1.1

Indonesia Stock Exchange (2020). Ringkasan Performa Perusahaan Tercatat. Data Pasar. Accessed on February 4, 2020 at https://www.idx.co.id/data-pasar/laporanstatistik/ringkasan-performa-perusahaan-tercatat/.

Jurnal Entrepreneur (2020). Ini 5 Sektor Bisnis Tahan Krisis saat Pandemi COVID-19. Dunia UKM. Accessed on Desember 20, 2020 at https://www.jurnal.id/ id/blog/ini-5-sektor-bisnis-tahan-krisis-saat-pandemi-covid-19/. 
Kasmir, K. (2012). Analisis Laporan Keuangan. Jakarta: PT Raja Grafindo Persada.

Khairudin, K., \& Wandita, W. (2017). Analisis Pengaruh Rasio Profitabilitas, Debt to Equity Ratio (DER) dan Price to Book Value (PBV) terhadap Harga Saham Perusahaan Pertambangan di Indonesia. Akuntansi \& Keuangan, 8(1), 68-84. http://jurnal.ubl.ac.id/index.php/jak/article/view/826/992.

Kusumawati, W. S., Topowijono, T., \& Endang NP, M. G. W. (2016). Pengaruh Profitabilitas, Kebijakan Dividen dan Risiko Sistematis terhadap Harga Saham (Studi pada Perusahaan Manufaktur yang Listing di BEI Periode 2012-2014). Jurnal Administrasi Bisnis S1 Universitas Brawijaya, 35(2), 127-135.

Lestari, A. P., \& Susetyo, A. (2020). Pengaruh NPM , EPS , DER dan PBV terhadap Harga Saham pada Perusahaan Terdaftar IDX HIDIV20 dengan DPR sebagai Variabel Intervening. Jurnal Ilmiah Mahasiswa Manajemen, Bisnis dan Akuntansi, 2(4), 184-196.

Mayangsari, R. (2018). Pengaruh Struktur Modal, Keputusan Investasi, Kepemilikan Manajerial, dan Komite Audit terhadap Nilai Perusahaan Sektor Aneka Industri yang Listing di Bursa Efek Indonesia Periode 2012-2016. Jurnal Ilmu Manajemen (JIM), 6(4), 477-485.

Mediawati, E., \& Afiyana, I. F. (2018). Dewan Pengawas Syariah dan Pengungkapan Sukarela pada Bank Umum Syariah di Indonesia. Jurnal Riset Akuntansi dan Keuangan, 6(2), 259-268.

Nasihah, L. (2017). Price Earning Ratio (PER) dan Price to Book Value (PBV) terhadap Return Saham dengan Earning per Share (EPS) sebagai Variabel Moderasi: Studi pada Perusahaan Telekomunikasi yang Listing di BEI Periode 2011-2016. Undergraduate Thesis, Universitas Islam Negeri Maulana Malik Ibrahim, 1(3), 43. https://www.oreilly.com/library/view/designing-data-intensiveapplications/9781491903063/\%0Ahttp://shop.oreilly.com/product/063692003217 5.do\%0Ahttps://www.packtpub.com/web-development/getting-startedwebrtc\%0Ahttps://www.oreilly.com/library/view/getting-s

Ningrum, N. M. W. (2017). Pengaruh Dividend Payout Ratio, Return on Asset, Return on Equity, dan Profit Margin terhadap Harga Saham pada Perusahaan Manufaktur yang Terdaftar di Bursa Efek Indonesia Tahun 2013-2015. Simci-Economic, 01(11), 1-16. https://doi.org/10.1.03.03.0022.

Novalia, F., \& Nindito, M. (2016). Pengaruh Konservatisme Akuntansi dan Economic Value Added terhadap Penilaian Ekuitas Perusahaan. Jurnal Ilmiah Wahana Akuntansi, 11(2), 1-16. https://doi.org/10.21009/10.21.009/wahana.011/2.1.

Nugraha, R. D., \& Sudaryanto, B. (2016). Analisis Pengaruh DPR, DER, ROE, dan TATO terhadap Harga Saham (Studi Kasus pada Perusahaan Industri Dasar dan Kimia yang Terdaftar di BEI Periode 2010-2014). Diponegoro Journal Management, 5(4), 1-12.

Oyedokun, G. E., Tomomewo, A. O., \& Owolabi, S. A. (2019). Cost Control and Profitability of Selected Manufacturing Companies in Nigeria. Journal of Accounting and Strategic Finance, 2(1), 14-33. https://doi.org/10.33005/jasf.v2i1.31.

Pranata, G., Purnamawati, I. G. A., \& Adiputra, I. M. P. (2015). Pengaruh Tarif Pajak dan Kebijakan Dividen terhadap Harga Saham (Studi Kasus pada PT Telekomunikasi Indonesia, Tbk. Periode 2001-2014). E-Journal S1 Akuntansi Universitas Pendidikan Ganesha, 3(1), 1-10. 
Ramadhana, A. A., Sjahruddin, H., \& Purnomo, S. H. (2013). Pengaruh Kinerja Keuangan terhadap Harga Saham. Jurnal Ilmiah Manajemen Kesatuan, 1(1), 4765. https://doi.org/10.37641/jimkes.v1i1.254.

Ratih, D., Apriatmi, A., \& Saryadi, S. (2016). Pengaruh Earning per Share dan Price Earning Ratio terhadap Debt to Equity Ratio dan Harga Saham pada Perusahaan Sektor Makanan dan Minuman di Bursa Efek Indonesia. Eksis: Jurnal Riset Ekonomi dan Bisnis, 11(1), 1-12. https://doi.org/10.26533/eksis.v11i1.36.

Risnanti, P., Kustiyah, E., \& Widayanti, R. (2019). Analisis Kebangkrutan Perusahaan yang Terancam Delisting di Bursa Efek Indonesia. Jurnal Maksipreneur: Manajemen, Koperasi, dan Entrepreneurship, 9(1), 1-16. https://doi.org/10.30588/jmp.v9i1.432.

Salam, A. F., \& Rohaida, I. (2019). Pengaruh Kebijakan Dividen terhadap Harga Saham dengan Ukuran Perusahaan sebagai Variabel Moderating (Studi Empirik: Perusahaan Sektor Pertambangan yang Terdaftar di Bursa Efek Indonesia Periode 2011-2015. Jurnal Ilmiah Ekonomi, 15(2), 141-154.

Sanjaya, S., \& Afriyenis, W. (2018). Analisis Fundamental terhadap Harga Saham Perusahaan Manufaktur Sektor Industri Barang Konsumsi. Jurnal Kajian Ekonomi Islam, 3(1), 72-84.

Senkus, A. W., \& Górna, J. (2021). Towards Sustainable Development: Risk Management for Organizational Security. Entrepreneurship and Sustainability Issues, 8(3), 527-544.

Silalahi, E., \& Manik, E. S. (2019). Pengaruh Dividend Payout Ratio, Debt Ratio dan Return on Asset terhadap Harga Saham pada Perusahaan Manufaktur yang Terdaftar di Bursa Efek Indonesia. Jurnal Riset Akuntansi dan Keuangan (JRAK), 5(1), 49-70.

Simorangkir, R. T. M. C. (2019). Pengaruh Kinerja Keuangan terhadap Return Saham Perusahaan Pertambangan. Jurnal Bisnis dan Akuntansi, 21(2), 155-164. https://doi.org/10.34208/jba.v21i2.616.

Sochib, S. (2019). Pengaruh Price to Book Value, Earning per Share dan Debt to Equity Ratio terhadap Harga Saham Bank Umum Swasta Nasional. Wiga: Jurnal Penelitian Ilmu Ekonomi, 9(1), 20-29. https://doi.org/10.30741/wiga.v9i1.408.

Suganda, T. R., \& Sabbat, E. H. (2014). Sinyal Profitabilitas dan Reaksi Pasar Modal Terkait Peningkatan Dividen Saat laba Meningkat. Jurnal Keuangan dan Perbankan, 18(3), 335-344.

Sugiyono, S. (2017). Metode Penelitian Kuantitatif, Kualitatif dan R\&D. Bandung: PT Alfabeta.

Sulistyowati, Y. (2011). Pengaruh Earning per Share ( EPS), Price Earning Ratio (PER), dan Dividend Payout Ratio (DPR) terhadap Harga Saham (Studi Empiris pada Perusahaan Food and Beverages yang Terdaftar di BEI). Jurnal Modernisasi, 8(3), 247-255.

Suwardjono, S. (2011). Teori Akuntansi Perekayasaan Pelaporan Keuangan. Edisi Ketiga, Cetakan Kelima. Yogyakarta: BPFE Yogyakarta.

Watung, R., \& Ilat, V. (2016). Pengaruh Return on Asset (ROA), Net Profit Margin (NPM), dan Earning per Share (EPS) terhadap Harga Saham pada Perusahaan Perbankan di Bursa Efek Indonesia Periode 2011-2015. Jurnal Riset Ekonomi, Manajemen, Bisnis dan Akuntansi, 4(2), 518-529. 
Yin, L., \& Nie, J. (2021). Adjusted Dividend-price Ratios and Stock Return Predictability: Evidence from China. International Review of Financial Analysis, 73(October), 1-18. https://doi.org/10.1016/j.irfa.2020.101618.

Yahoo Finance (2020). Trending Tickers. Accessed on February 7, 2020, at https://finance.yahoo.com/lookup?guccounter=1.

Yulyanah, Y., \& Kusumastuti, S. Y. (2019). Tax Avoidance pada Perusahaan Manufaktur Sektor Industri Barang dan Konsumsi Sub Sektor Makanan dan Minuman yang Terdaftar di Bursa Efek Indonesia Periode 2013-2017. Media Ekonomi, 27(1), 17. https://doi.org/10.25105/me.v27i1.5284. 